\title{
A Marxist Approach to Communication Freedom
}

\author{
Slavko Splichal
}

\author{
University of Ljubljana, Slovenia, slavko.splichal@guest.arnes.si, \\ http://www.sazu.si/clani/slavko-splichal, ORCID iD: https://orcid.org/0000-0001- \\ 7678-2676
}

\begin{abstract}
This article is an abridged translation of the section "Produkcija in komuniciranje: nujnost in svoboda" (Production and communication: necessity and freedom) of Slavko Splichal's book Množično komuniciranje med svobodo in odtujitvijo (Mass Communication between Freedom and Alienation, pp. 123-138), published in Slovene in 1981 after it was defended as a doctoral thesis in 1979. The article, which was among the earliest on its topic, starts with the discussion of Marx's approach to the freedom of the press in his "Proceedings of the Sixth Rhine Province Assembly", from the perspective of his later economic critique of capitalism, to show the inherent connection between human communication and work. This indissoluble connection is the starting point of the critique of "critical theories" aiming at "liberating" communication from work and production, exemplified by Habermas's dualistic conception of work and communication. The concluding part discusses the relationship between communication freedom, rationality, and alienation, arguing that the freedom of communication cannot be founded on its independence from work (material production), but only on the emancipation or disalienation of human labour, and emphasising the danger that, if this does not happen, one-party socialist system with state and social ownership of the means of production and state-controlled economy will deteriorate into a multiparty capitalist system with private ownership and monopolistic economy. The article is followed by an afterword in which the author writes in a retrospect, after 40 years, about political and intellectual circumstances of the self-management socialism, which shaped the development of communication and media studies in "late socialism" - i.e. in the period preceding and heralding the collapse of socialism.
\end{abstract}

Keywords: communication freedom, rationality, production, productive forces, labour, Marx, Habermas

\section{Introduction}

Critical communication scholars have long had a central interest in social class structure as one of their main concepts, as it affects communication, along with the associated concepts of conflict, domination, and dialectic. [...] More correctly stated, social class was an important concept for critical scholars in understanding society, although this concept (1) has undergone substantial revision by Habermas $(1976,130-177)$ in recent years, and (2) always was much more important for orthodox Marxist scholars than for critical scholars (E. Rogers 1981, $131 ; 141)$.

The purpose of this article is to support Rogers's call for a better understanding of the critical (Marxist) theories of communication which may have useful implications for empirical research and communication development in practice. More specifically, what this article calls for is (1) the elaboration of basic concepts developed by Marx in his earliest analyses of the freedom of the press and censorship from the point of view (2) 
of his later criticism of political economy (e.g. in Grundrisse and Capital) and (3) attempts of some critical scholars to revise Marx's concepts and method. The need to elaborate Marx's original ideas and confront them with the contemporary criticisms and revisions, that of Habermas being the most prominent among them, sterns from structural changes of modern societies as well as development and growth of communications themselves, and from the fact that differences within the critical scholarship are not only of theoretical significance but rather have practical, political consequences in communication policy planning.

The central concept of Marx's articles on communications is the concept of the freedom of the press. On the one hand, his analyses are focused on the generic characteristics of the freedom of the press as a specific human activity; on the other hand, he explores the conditions in which the press loses its freedom or because of them could never reach it, and becomes subordinated to privileges originating from production relations and unequal social distribution of wealth. A great deal of contemporary controversies among critical communication scholars (e.g. Franz Dröge, Horst Holzer, Wulf D. Hund, Dallas Smythe, Nicholas Garnham, Graham Murdoch, Bill Livant) stem precisely from the problem Marx was faced with: the problem of (in)dependence of communication from work (production) and vice versa, and the problem of the nature of interrelationship between the two.

\section{Marx's Approach to Freedom of the Press}

Among the rights and freedoms of men and citizens gained by the bourgeois revolution, freedom of the press - as the right of citizens to speak, write and publish freely has been declared from the very beginning at the level of the individual, as a personal right, practically inseparable from the right of property. In his early "Proceedings of the Sixth Rhine Province Assembly", Marx argues against such a conception of the "free press" and denotes it as a "special prerogative," "a privilege of an individual", which is his right only in as much as it is not the right of his fellowman at the same time, so that the freedom of the one turns out as the unfreedom of the other, and does consequently not differ essentially from the state bureaucratic censorship as the most salient negation of the freedom of the press. The realisation of the bourgeois declaration of the freedom of the press is in fact only the freedom of ownership, which is far from a genuine freedom of the press. This winds up the process of transformation of the public character of the early revolutionary bourgeois press into its formal frames as the negation and not the affirmation of the freedom. Marx argues that the true interest of the bourgeoisie as the ruling class is not to eliminate unfreedom of the press in general, but rather to substitute one kind of unfreedom (external unfreedom, i.e. censorship), which hinders the free exercise of ownership in the sphere of the press, for another (internal) unfreedom. The bourgeoisie considers it a "classical inconsistency" if the sphere of the press were to be exempt from the general entrepreneurial freedom (Marx $1842 / 1976,88)$. But as long as freedom of the press is derived from the freedom of ownership, it will in fact remain but a privilege - not a right of the man, but a right of the owner, which means the monopolised right. In Marx's perspective, the simple declaration of freedom of the press can be surpassed only to the extent to which the sphere of the press is considered in its essential nature; not in its external relations, but as the embodied confidence of the people in themselves, as a possibility of a free communicative union of people. On the other hand, the press can also be treated as an enterprise, but it is then no longer a matter of writers but rather the domain of publishers and editors. Such a practical reductionism of the concept of freedom of the press would 
exclude the specific in the communication sphere: the possibilities of its "subordination" to the laws of its own sphere and not to those of other spheres of human activities.

However, scrutinising the specifics of the communication sphere could not be validly conducted without taking into account the laws of the prevailing mode of production (social, production relations), as a great deal of critical theories seem to do. In his criticism of the "civilisation approach", Marx proves that mental production (including the press) can be truly explained only in its relations to the material production, when (1) material production is not conceptualised as production in general, but as a particular historical mode of production, and (2) when explored (a) how social relations and (b) the relation of individual to nature are integrated into specific form of material production, both ( $a$ and $b$ ) determining the mode of mental production as production sui generis, as a specific kind of human activity (Marx 1863/1974, 257). The specific nature of (mass) communication in relation to the production that determines the position and the social impact of all other kinds of production and social relations is reflected primarily in the specific relation established between the prevailing mode of production and its general laws, and certain special form of production, special kind of human activity, such as communication.

The exploration of the possibilities and conditions of a real emancipation of the communication sphere must be based on the explanation of the relations between (1) the general laws of production relations and of relations ensuring or conditioning the domination of one sphere of human activities over another (e.g., the domination of the production of surplus value for capital), and (2) their specific affirmation in the communication sphere. Thus, a real explanation of the specific character of the communication sphere in a society cannot be confined to the establishment of "the universal differences" between single moments in specific forms of human activity. On the contrary, it has to start from the totality of the processes of social life, which is the more only an abstract totality, the more alienated specific forms of social relations are - and then the communication sphere also seems to have become "independent" already. The apparent independence of the communication sphere even suggests that "communication as such [...] should become the central category for the social scientific theory of communication," for it seems that "work is only an economic category" and consequently irrelevant for the theory of communication narrowed to the content production as a natural human ability aiming only to meet human communication needs (Gehrmann 1977, 10; Beth 1976, 61). But the development of social relations reveals the pure illusion of the isolation of communication phenomena from social, production relations. The ability to communicate is not something "given by nature," but created, "produced" by past generations (past labour); it is in fact the result and existential condition of the production process (work). Hence, the study of social communication cannot be validly reduced only to the subjective, e.g. to the relation between abstract individuals aiming to establish cooperation among those who communicate, without considering its essential (material) conditions and circumstances. Yet it would be also erroneous to simply subsume communication under the general laws of the prevailing mode of production, without defining specific conditions and characteristics by which communication can only be (and has been) constituted as a specific social activity.

The analytical categories "work", "communication", "material production", "mental production" etc. are not discrete forms of the existence of social phenomena and therefore cannot be validly observed and explained if separated from each other, but only in their mutual interrelationship. Otherwise, the process of explanation is bound to result in economic determinism, which reduces the study of communication either to searching for the general laws of the prevailing mode of production in concrete forms 
of communication, or to an ahistorical conceptualisation of forms and structures of communication without conceiving the concrete social conditions of communication activities. The latter tendency is clearly present in a considerable part of contemporary communication schools of thought, which implicitly or explicitly set the focus on the emancipation of the communication sphere - in the functional as well as in the critical theories of communication. The theories of communicative competence (e.g. Badura, Gehrmann, Habermas) are the ones to be listed among the most consistently set up dualistic theories of work and communication, thus challenging Marx's theory and method. The separation of work and communication from each other reaches its climax in the theoretical consistency with the work of Haberrnas. Due to its contemporary intellectual reputation, it is important to examine some of the questions about Marx's theory and method raised by this theoretical perspective, and to confront them with the original Marx's ideas.

\section{Habermas vs. Marx: The Supremacy of "Communicative Action" over Produc- tion?}

As it is well known, Marx did not produce a consistent communication theory, although his analyses offer ground stones for it, as it is clear from contemporary critical theories either elaborating or just criticising "Marx's theory". At the time when Marx published his essays on the press, he did not yet developed his method and theory as they are known from his later work, while in his later works, the press was not in the focus of his main research interests any more. Thus, the connection between the "young" and the "old" Marx remains to be a subject of different interpretations (and misinterpretations, when his ideas from different periods are taken isolated from each other).

The significance of Habermas's criticism addressed to Marx is in the fact that it is focused on Marx's basic concepts. The central point of Habermas's criticism is an attempt to revise Marx's concept of relationship between the productive forces and production (social) relations, and to lose it in an independent, self-supporting logic ("rationality") of the material production out of production relations and separated from human communication activity. What is the core of Habermas's position versus Marx from the point of view of communication theory building?

Habermas postulated a mutual independence and empirical separation of labour and interaction, in contrast to Marx's dichotomy "productive forces-production relations", by which Marx supposedly overlooked interaction as a constitutive dimension of human species and thus "eclipsed the idea of social science by equating it with the natural science," and reduced human history to natural history (Habermas 1975, 87; 97). That is why Marx's paradigm "productive forces - production relations" should be replaced with "a more abstract relation between work and interaction."

While instrumental action ${ }^{1}$ corresponds to coercion of external nature and the state of productive forces determines the extent of the technical disposal of natural forces,

1 'By 'work' or rational action (zweckrationales Handeln) I mean either instrumental action or rational choice, or else the combination of both. Instrumental action follows technical rules based on empirical knowledge. These always imply conditional prognoses of perceivable events, physical or social; they can turn out to be valid or false. On the other hand, communicative action (kommunikatives Handen) denotes the symbolically conveyed interaction. It conforms to the mandatory valid norms that define reciprocal expectations of behaviour and must be understood and acknowledged by two acting subjects. [...] While the validity of technical rules and strategies depends on the empirically true or analytically correct sentences, the validity of social norms is founded exclusively on the intersubjectivity of understanding 
the communicative action corresponds to the mastery of man's own nature: the institutional framework determines the extent of repression by the self-supporting force of social dependence and political power. Society owes its emancipation from the external forces of nature to the processes of work, namely, to the creation of technically applicable knowledge [...]; the emancipation from the coercion of internal nature prospers in as far as the authorised (Gewalt habende) institutions are replaced by the organisation of social intercourse (Verkehr) related only to the nonauthorised (herrschaftsfreie) communication. This is not brought about directly through production activity, but through revolutionary activity of the struggling classes (including the critical activity of reflexive sciences) (Habermas 1975, 85).

For Habermas, the constitutive moment of social relations is communication and not work (production), since "production or social labour is the instrumental action in conditions of rational cooperation" (Habermas 1971, 277). Although production is here formally identical with social labour, and rational cooperation is the condition of instrumental action, Habermas's "instrumental action" in fact covers only Marx's simple moments of the process of production (work) - "rational activity or work proper, the object worked upon and the means worked with." These moments are eternal natural conditions of man's life and consequently independent from all forms of his life, thus common to all its social forms as long as the worker is not treated in relations to other workers.,

However, Marx understands work "primarily (zunächst) as a process between man and nature" (Marx 1867/1961 [Kapital I], 201), and thus not exclusively so: individuals appropriate nature always "within the framework of a particular social form and with its support" (Marx 1857/1953 [Grundrisse], 18). In production process thus individuals do not relate to nature only; they produce only by cooperating among themselves in some way and by exchanging their activities. The main result of production process is not a material product: in capitalism, the main result is

the reproduction and the new production of the relation of capital and labour itself, of capitalist and worker. This social relation, production relation, appears in fact as an even more important result of the process than its material results. And more particularly, within this process the worker produces himself as labour capacity, as well as the capital confronting him, while at the same time the capitalist produces himself as capital as well as the living labour capacity confronting him (Marx 1857/1953 [Grundrisse], 362)

In his criticism of the bourgeois political economy, Marx in a way "anticipated" Habermas when he stated that economists "foist underhand the bourgeois relations as the incontestable natural laws of society in abstracto," when they claim that "production is unlike distribution [...] integrated into historically independent natural laws," as opposed to distribution, in which people would afford "any kind of arbitrariness" (Marx 1857/1953 [Grundrisse], 17). This "anticipation" applies to Habermas's criticism of Marx's conception of production as determining social distribution: according to Habermas, distribution is not determined by production but by "the institutional framework" (Habermas $1975,85 ; 87)$, as if the ownership relation would be independent from production.

Habermas disregards the most important part of Marx's elaboration of social development - the historical process and laws of division of labour, which is not only (like

about intentions, and is secured by the general acknowledgement of obligations" (Habermas 1968, 62; Habermas 1971, 219-220). 
work itself, in abstracto) an eternal indispensable condition of the existence and development of society, but at the same time also the basis of a particular social organisation (Habermas 1971, 277-279). Only if the historical dimension of the process of division of labour is not borne in mind, one can come to the conclusion that,

The institutional system regulates the interactions of groups and individuals. The institutional framework of production, which regulates the distribution of burdens and compensations, resources and life opportunities, the distribution of the means of production and the privileges of appropriation of the socially produced wealth, is subsumed by Marx under the title of production relations. The institutional system consists, whether it regulates processes of production directly or social exchange in other spheres, of rules of communicative action or symbolically mediated interaction. These are intersubjectively acknowledged norms that define mutual behavioural expectations for at least two subjects capable of speech and action. (Habermas 1971, 278)

With this conceptual leap over (production relations - institutional system - rules of communicative action), Habermas reduces the problem of human disalienation to the emancipation of/in the communication sphere, and the latter to the "sublimation of the oppression of institutional framework", with the objective to get to "an organisation of society based exclusively on discourse free of authorities" (Habermas 1975, 89).

Habermas's "decisive point" that the late capitalist social system is strategically vulnerable in the sphere of politics and not in the sphere of economy, since the economic interests of consumers and employees are satisfied while the political interests are supressed and the public depoliticised (Habermas 1969, 651), does not only neglect that the sort and magnitude of "economic interests" (needs) are historically/socially developed and that they include cultural and moral elements (e.g. "economic needs" vs. need for leisure). Above all, Habermas's "decisive point" is not a proof of the general supremacy of communicative action over production. Aspiration towards fulfilling radical, suppressed interests is certainly a condition for radical change, for the establishment of relations in which new needs, quantitatively and/or qualitatively different interests can be fulfilled. But mutually acknowledged interests of "consumers and employees" are not the sufficient condition to change a social system, since development of a new system needs some kind of passive element - some material basis. Luhmann justifiably denotes Habermas's procedure of abstraction as "introducing 'idealising' assumptions that are merely based on being anchored in a concept of truth, which in turn can only be clarified by reference to discourse, and an excessively language-centred communication theory" (Luhmann 1971, 338). Indeed, it is difficult to see "how the essentials of the life-relations of people could be changed or how people could be shaped in such a way that the truthfulness of the arguments of the validity is discussed by rulers or someone else attempting to reach a reasonable consensus about them" (Luhmann 1971, 293).

The close ties between - if we stick to Habermas's terms - instrumental and communicative actions become clearly evident in the communication sphere itself with the implementation of complex technology into the production and dissemination (exchange) of messages. In Habermas's analyses of communication (communicative action or interaction and discourse) as a non-instrumental activity per definitionem ("exchange of information" in interaction and "reaching consensus" and "rational criticism" in discourse, from which "all the motives except of cooperative readiness for consen- 
sus" are excluded; Habermas 1971, 117), communication as a process of content production, as the totality of mental and material production is excluded. In his study of (the disintegration of) the public in the advanced capitalist society, the attention is thus limited to the final state or consequences of the transformation ("acclamation" instead of "reasoning" in the public sphere), without including its decisive "exterior," i.e. material conditions and causes. In this way, the illusion of the independence of communicative action comes to being, i.e. that the public can be reconstituted merely by the changes in the sphere of communicative action alone.

Habermas's critique of Marx's that his conceptualisation of social practice reduces interaction to work and that, therefore, he sought in vain the solution for human emancipation in the dialectics of productive forces and production relations, is not at all completely new. The one-sidedness of such claims indicating the misinterpretation of Marx was pointed out already by Lenin's polemics against Michailowski, who discovered "the conflict between the idea of historical inevitability and the importance of personal activity" and hence concluded that Marx's thesis of the prevailing production relation determining all other relations is "fruitless" and "deterministic." As Lenin argued,

The idea of determinism, which postulates that human acts are necessitated and rejects the absurd tale about free will, in no way destroys man's reason or conscience, or appraisal of his actions. [...] Similarly, the idea of historical necessity does not in the least undermine the role of the individual in history: all history is made up of the actions of individuals, who are undoubtedly active figures. The real question that arises in appraising the social activity of an individual is: what conditions ensure the success of his actions, what guarantee is there that these actions will not remain an isolated act lost in a welter of contrary acts? (Lenin 1949, 109; emphases added)

With Habermas's "emancipation" of communication from man's material production, the subjective is in fact isolated from the objective (and within the subjective, the rational from the sensory), whereby "cognition is cut off from practice" (Mao 1972, 23). What Habermas actually overlooks is not only that communication is "material" in the sense that it takes individuals' time which is only available after the material needs are satisfied (i.e. in the sense of the social superstructure), but also that communication is - like material production - the propelling force of historical development, including the development of material production itself, yet by no means separated from historical premises, from individuals' actual, material process of life. Habermas's misperceives the antagonism between instrumental and communicative actions as dualism of mutually independent kinds of actions. Since the relative improvement of the position of the working class is seen as a complete abolition of the antagonism between wage labour and capital ("deprived and privileged groups [...] no longer oppose each other as socioeconomic classes"), the sphere of material production becomes irrelevant for "the revolutionalisation of the late capitalist social system" (Habermas 1969, 650). Thus, the only revolutionary potentials left are to be found, according to Habermas, in the sphere of communicative action alone, which consequently acquires its own logic.

In the empirical world, the practical "independence" of communicative action from instrumental action is manifested in that the latter is not thematised by the former in the developed capitalist societies. The concrete historical basis of Habermas's dualism of work and communication can be found in the advanced capitalist society, where instrumental actions are in fact excluded from communicative actions, as Knipping and Alberts empirically verified with a simple analysis. They compared the population structure in Western Germany with the structure of "social statuses" represented in German television programmes, and came to a "scandalising" conclusion that only four percent of the TV programmes cover the world of labour, whereas workers and employees 
represent ninety percent of in the total German population (Hund 1973, 18). According to another empirical analysis, there exists a basic contradiction between the predominantly progressively oriented general population and the conservatively oriented part of population and economic elite supported by the majority of Dutch daily newspapers with two thirds of the total newspaper circulation, the latter being significantly positively correlated with the amount of advertisements expanding the commodity production (van Cuilenburg 1978, 15; Oorburg et al. 1978, 50-51). While Modelmog (1973, 30) argues that the contents of mass media in a capitalist system "reinforce alienation through the concealment of the antagonistic opposition" with "the norms as functional, general social contents of consciousness" directing individuals' actions, Habermas on the unwarranted assumption of the abolition of class antagonisms in the sphere of production - comes to the conclusion that the rules of communicative action are independent from the social production process.

\section{Communication Freedom and Rationality: A Challenge for Reconsideration}

According to Habermas's dualistic conception of work and communication and division of the latter in interaction and discourse ${ }^{2}$, the rationality (Vernünftigkeit) of discourse can only be secured by the functional supremacy of science $(1968,285 ; 1975,84)$, as opposed to the rational choice in instrumental (rational) action. Owing to rationality, communication can be liberated from its subordination to the political system as it was in traditional societies (i.e. to censorship) or to the economic system as in capitalism (i.e. to the freedom of ownership). However, Habermas ignores the possibility that communication can be nevertheless subordinated - to the meritocratic supremacy of science as a specific human practice, i.e. to the scientists. Thus, it would remain but a privilege of the minority rather than universally accessible to the majority of mankind, those producing material conditions of life. For Habermas, participants in discourse are not "under the pressure of action" (Handlungszwang); man's practical interests are excluded from the discourse on the assumption of "an effective equality" - "a symmetrical distribution of opportunities to choose and utter speech acts" - and not only on the assumption of "exchangeability of the roles of dialogue in principle" (Habermas 1971, 137-138). The material premises of the assumed ideal discursive situation, i.e. possibilities and conditions of its practical achievement or realisation, are considered irrelevant: the rationality of discourse is not determined by the empirically truthful (ir)rationality of instrumental action and interaction, of human (social) interests, but only by the "truthfulness of expressions" (Wahrhaftigkeit der Äusserungen) as "deceiving neither a speaker himself nor others" $(1971,131)$. Yet as Bertalanffy $(1973,122)$ proves, such an assumption is empirically delusive because "the 'principle of rationality' fits - not the majority of human actions but rather the 'unreasoning' behaviour of animals. Human behaviour, on the other hand, falls far short of the principle of rationality" as the consequence of coupling biological factors with symbolic values.

Moreover, rationality is not ahistorical. The historical dimension of (social) rationality, which applies to human affairs, could be defined in terms of the choice of the optimum way to achieve specific objectives - e.g., to maximise social welfare. In this specific sense, any society tends to regulate social relations in a rational way. The point is, however, that the criteria of rationality are being changed with the development of

${ }^{2}$ In interaction, information (experiences related to actions) is exchanged. In discourse, in contrast, participants try to (re)achieve the validity of norms and opinions, which is why it precludes all the motives except of the co-operative readiness for coming to an agreement (see Habermas 1971, 115-117). 
productive forces, in accordance to the ruling interests and the dominant mode of production. Like productivity, as Marx kept pointing out, rationality cannot be defined "in general" or universally, but only in the historically determined framework of a concrete society. The same applies to the "truthfulness of expressions" as the yardstick of "the rationality of discourse." The measure of the truthfulness of an idea has to be related to the human ability to implement it in practice, which in turn also depends on the empirical interest in practical actions and not only on the feasibility of ideas. The development of productive forces raises the issue of new (possible) criteria of the rational regulation of social relations the more intensely, the greater the gap between the level of the development of productive forces and the inappropriate (thus "irrational") production relations. But only the idea itself of the (new) criteria of social rationality or even of "the emancipation from the pressure of action" does not change relations at all.

The only rationality for the capital is the production of surplus value for the value increase of capital and such a social system that will ensure the realisation of this direct objective and defining purpose of production determined by the interest of the ruling class. The capital relation thus becomes also the criterion of the rational regulation of social relations, including the specific sphere of communication. On the other hand, the criteria of rational regulation of social relations in a postcapitalist society are per definitionem no more rooted in the interest in the value increase of capital, since the main objective is no longer the production of exchange value but of use value. In view of the criteria of rationality in the capitalist system, social relations in a postcapitalist society are regulated irrationally, just as capitalist social relations appear to be irrational from the perspective of a socialist society.

Further analysis along these reconsiderations provides an evidence that the use value of mass produced media contents in monopoly (or state) capitalism is determined by the interest of the capitalist class in production of surplus value rather than use value in terms of the recipients' needs. This is a double way determination: (1) stimulating the individual production of consumption capacity, which is a presupposition of the value increase of capital, and (2) legitimising the prevailing capital relation, a "peaceful coexistence" of labour and capital. The result is that the recipient's material and intellectual enrichment (consumption of advertised commodities and education/socialisation) in the process of mass communication becomes in fact his impoverishment (surplus labour and adjustment of consciousness to alienated social relations); the apparent compensation for alienation is in fact its strengthening.

Paradoxically, the conservative legitimisation of bureaucratic privatisation of the communication sphere in state socialism arises from (uncritical absolutisation of) Lenin's thesis that the revolutionary press is the "collective propagandist, collective agitator, and collective organiser," and his differentiation between state capitalism and state socialism. In "the theories of the press of new (socialist) type" prevailing in socialist countries, the danger that one-party socialist system with state and social ownership of the means of production and centrally controlled economy could deteriorate into a multiparty capitalist system with private ownership and monopolistic economy, has never been considered. However, the only difference (if one can speak about any essential difference at all) in the negation of communication freedom between the developed capitalist system and state-socialist system is that in the former, the prevailing activities are primarily focused on the production of individuals' consumption capacity and acquisition of commodities (in advertising), while in the latter - because possibilities of individual consumption are restricted by the underdeveloped "economic base" and the central state plan - they are directed toward the development of the individual 
labour power (in propaganda). In both cases, the main aim of the mass media is increasing the amount of surplus value as the economic foundation of political power alienated from the workers, rather than developing their human capacities as social beings - an example of how the logic of capital persisted even in self-management socialism. The material unfreedom of communication and dependency of the communication sphere (its subordination to the entrepreneurial freedom) and its intellectual unfreedom (subordination to state/bureaucratic censorship) are only two different forms of the same misfortune.

To avoid this practical danger of historical regression, the idealistic view on the development of an independent communication sphere in socialism should be substituted by a well-founded analysis of the possibilities and obstacles of socialisation of communication.

Nevertheless, as the most general criterion of productive labour is always the same and common to all historical modes of production - i.e. the surplus labour as the labour which exceeds the satisfaction of the existing needs - a general "principle of rationality" also exists. It applies to the realm of necessity in relation of human beings to nature or, according to Habermas, to the technical rules. Beyond it, the real realm of freedom begins. The principal contradiction of the development of society after the abolition of the prevailing capital relations is in the very fact that the true realm of freedom flourishes only on the foundations of the realm of necessity, so that all by-passes to avoid the necessity of consolidating the material base are averse to the true realm of freedom as well.

The material structure of society defines and affects communication activity of social actors at two levels: (1) As any other human activity, if it is truly rational, communication has to be subordinated to the laws of nature (including human nature) and historical development of society, which first of all requires that we unveil and understand them. (2) The realisation of possibilities for equal participation of all social actors in the communication sphere presupposes the establishment of an adequate material communication system. The conditions at the first level define the rationality of the content (subject\} of social communication, while the conditions at the second level define the course of communication, its procedure, which is by no means merely a "procedural issue", since it in turn affects the formation of human consciousness.

Only by taking into account the conditions of "instrumental behaviour," social communication actually becomes an instrument of mastering natural and social laws and thus directing social development. Otherwise, communication ("communicative action") unavoidably has only an alienating effect because it preserves and reproduces the old alienated social relations by offering to the masses the illusion of an unmanageable complexity of the empirical, material world, and consequently dissuading them from practical action to change it.

The close connection between forms of communication and the complexity of productive forces and production relations is clearly reflected in Marx and Engels's observation that writing marks the first all-inclusive transformation of human relations in history - not only the transition from a primeval, classless human community to civilisation, but also its transition to class society (Marx and Engels 1848/1908, $14 \mathrm{n}$ ). The invention of handwriting was not only a major technological breakthrough that made civilisation possible, but it also enabled a new form of social division (differentiation) that consolidated and strengthened the existing technical divisions of labour, because the product of writing (message) was separated - in contrast to previous non-recorda- 
ble spoken communication - from the act of writing (production). Thus, the revolutionary communication invention of writing not only marks the beginning of a new cultural formation, but also the beginning of class society.

Human communication seemed to be a "natural skill" of human beings only as long as the development of production relations did not reveal its dependence upon material conditions, its instrumental character in production relations, and thus the fact that one can be alienated from this "natural skill" as s/he is in the labour process. While the relation of an individual to his language in a primary community is indeed the relation of a natural member of a human community, it is also a product of the community already - in contrast to the primary conditions of production as the real natural presuppositions, which do not result from human production.

History abounds with the evidence that the revolutionalisation of the communication sphere requires not only the revolutionary masses to seize the intellectual potentials. They also have to seize the material productive forces of the total (including mass communication) production, because the actual emancipation can only be carried out in a concrete material world with concrete means. The ability to communicate is - like the ability to work - a specific human quality, need and generic essence. If this activity is alienated from individuals or even from the majority of people at the present level of social and technological development - which is typically the case in mass communication -, this is not a consequence of the "natural" division of labour, but the legacy of the class division of labour. We must not forget that the ability and need to communicate are closely related to the development of any human ability and activity. This is even more empirically true when the communication sphere is industrialised, and hence directly integrated into the material production through its subordination to the prevailing mode of production.

Freedom of communication does not exist and never existed in its independence from the sphere of work (material production), but in that it is not subordinated to any particular external rationality or alien freedom of another particular human activity, such as freedom of ownership and entrepreneurship. Not only does the development of human creative potentialities for its own sake - the true realm of freedom - flourish only on the realm of necessity (production) as its base; it does flourish only if work itself becomes really free within the framework of necessity, so that (1) its social character is asserted, (2) work (not only communication as according to Habermas) becomes of scientific nature - "not merely human exertion as a specifically harnessed natural force, but exertion as subject, which appears in the production process not in a merely natural, spontaneous form, but as an activity regulating all the forces of nature" (Grundrisse [Marx 1857/1953], 505). Marx, unlike Fourier, does not see the free intellectual work as a game and mere entertainment, but at the same time as "the most damned seriousness, the most intense exertion" (ibid.) to fulfil certain objectives - yet the objectives set by man himself, i.e. in the work that is not subordinated to external rationality, but to the self-affirmation of man.

The emancipation of work is the prerequisite of the discursive rational communication; the unity of work and communication can only be based on the abolition of the antagonisms between work and communication. Only then, communication is "subordinated" to social agreement as the determining aim, as the only criterion of rationality. The process of reaching agreement is not only a mode of communication but also a mode of organisation, including the management of social production according to the criteria of social utility, whereby decision-making ceases to be a special function of bureaucracy, and politics a special kind of monopolised human activity. Social agree- 
ment as the purpose and main result of social communication is the negation of monopolistic management and supervision necessary in all modes of production based on the antagonism between the direct producer and the owner of the means of production, and consequently the negation of management as an activity alienated from production - it is therefore also a mode of practical exercise of producers' self-management. As long as producers have no possibility to decide democratically on conditions, means and results of their own and globally associated work, their basic "instrumental" interests and needs are in fact, as in Habermas's theory, excluded from social communication, and communication reduced to a monopolised activity because of its subordination to the particular interests embodied in "the functional supremacy" of economy, politics, science, or any other specific activity.

\section{References}

Bertalanffy, Ludwig von. 1973. General System Theory. Harmondsworth: Penguin.

Beth, Hanno and Harry Pross. 1976. Einführung in die Kornrnunikationswissenschaft. Stuttgart: W. Kohlhammer, 1976.

Cuilenburg, Jan van. 1978. Measurement of a Newspaper's Political Progressiveness. MDN Methoden en Data Nieuwsbrief van de Sociaal Wetenschappelijke Sectie van de Vereniging voor Statistiek, 4-17.

Gehrmann, Wolfgang. 1977. Disparate Kommunikation. Bochum: Brockmeyer.

Habermas, Jürgen. 1975. Saznanje i interes - Erkentniss und Interesse. Beograd: Nolit.

Haberrnas, Jürgen. 1971. Theorie der Gesellschaf oder Sozialtechnologie? In J. Habermas and N. Luhmann, Theorie der Gesellschaft oder Sozialtechnologie, 142-290. Frankfurt: Suhrkamp.

Habermas, Jürgen. 1969. Pogoji za revolucioniranje poznokapitalisticnih družbenih sistemov. Teorija in praksa (4): 645-655.

Habermas, Jürgen. 1968. Technik und Wissenschaft als "Ideologie”. Frankfurt: Suhrkamp.

Hund, D. Wulf, ed. 1973. Komrnunikationstopologie. Frankfurt: Europäische Verlagsanstalt.

Lenin, Vladimir I. 1949. Kdo so prijatelji ljudstva in kako se bore proti socialnim dernokratom? [What the "Friends of the People" are and how They Fight the Social-Democrats]. Izbrana dela (Selected works) vol. 1, Ljubljana: Cankarjeva založba.

Luhmann, Niklas. 1971. Systemtheoretische Argumentationen. In Jürgen Habermas and Niklas Luhmann: Theorie der Gesellschaft oder Sozialtechnologie, 291-405. Frankfurt: Suhrkamp.

Mao, Tse-tung. 1972. Über Praxis und Widerspruch. Berlin: Wagenbach.

Modelmog, Ilse. 1973. Methodische Überlegungen zur Massenkommunikationsforschung. In Franz Dröge: Wissen ohne Bewusstsein, 17-33. Frankfurt: Athenaurn.

Marx, Karl. 1867/1961. Kapital, Vol. 1. Ljubljana: Cankarjeva založba.

Marx, Karl. 1863/1974. Theorien über den Mehrwert (Marx-Engels Werke, Vol. 26.1). Berlin: Dietz Verlag.

Marx, Karl. 1857/1953. Grundrisse der Kritik der politischen Ökonomie. Berlin: Dietz Verlag.

Marx, Karl. 1842/1976. Debatten über Pressfreiheit und Publikation der landständichen Verhandlungen. In Karl Marx and Friedrich Engels: Werke I, 28-77. Berlin/DDR: Dietz Verlag.

Marx, Karl and Friedrich Engels. 1848/1908. Komunistični manifest (Manifesto of the Communist Party). Idrija: Naprej.

Oorburg, J., Th. van Boven, J. de Bruyn, and D. Jolink. 1978. His Master's Voice: Yes or No? MDN Methoden en Data Nieuwsbrief van de Sociaal Wetenschappelijke Sectie van de Vereniging voor Statistiek 1, 28-57.

Rogers, Everett M. 1981.The Empirical and the Critical Schools of Communication Research. In Communication Yearbook 5, edited by Michael Burgoon, 125-144. New Brunswick, NJ: Transaction Books. 


\section{About the Author}

\section{Slavko Splichal}

Slavko Splichal is Professor of Communication and Public Opinion at the University of Ljubljana's Faculty of Social Sciences, member of the Slovenian Academy of Sciences and Arts and Academia Europaea - The Academy of Europe. He is founder and director of the European Institute for Communication and Culture and Editor of its journal Javnost-The Public. He was member of the International Council and Deputy Secretary General of the International Association for Media and Communication Research and has been on the editorial boards of the International Journal of Public Opinion Research, Journal of Communication, Journalism Studies, Gazette, New Media and Society, and many others. Since 2011 he is Chair of the Advisory Board of the European Communication Research and Education Association ECREA. 